\title{
INVESTIGATION OF GEOTECHNICAL SPECIFICATIONS OF SAND DUNE SOIL: A CASE STUDY AROUND BAIJI IN IRAQ
}

\author{
Abbas J. Al-Taie ${ }^{1}$, Yousif J. Al-ShaKarchi ${ }^{1}$ ANd Ali A. Mohammed ${ }^{2}$ \\ ${ }^{1}$ Department of Civil Engineering, College of Engineering, University of Baghdad, Iraq. \\ ${ }^{2}$ Department of Civil and Structural Engineering, Faculty of Engineering, \\ National University of Malaysia UKM, 43600 UKM Bangi, Selangor Darul Ehsan, Malaysia.
}

abbasjaltaie@yahoo.com

\begin{abstract}
While more than half the land surface of Iraq consists of deserts covered mainly with sand dunes, little research has taken place to study the characteristics and the behaviour of dune soils. This paper investigated the Geotechnical properties of dune sands taken from Baiji city, the northwest part of Iraq. A vast laboratory testing program was carried out to achieve the purpose of this paper. The physical tests, chemical tests, X-ray diffraction analysis, permeability test, compaction characteristics, compressibility and collapsibility tests as well as the shear strength tests were included in this research. The results indicate that the soil of Baiji sand dune tends to favour the engineering properties according to their state. As such, this soil is considered suitable to use in Geotechnical constructions.
\end{abstract}

ABSTRAK: Walaupun lebih separuh daripada bumi Iraq terdiri daripada gurun yang dipenuhi dengan bukit-bukit pasir, tidak banyak penyelidikan dijalankan untuk mengkaji sifat-sifat dan ciri-ciri tanah pasir tersebut. Kertas kerja ini menyelidik sifat geoteknikal bukit pasir yang diambil dari pekan Baiji (di bahagian barat utara Iraq). Program penyelidikan makmal yang menyeluruh telah dijalankan bagi mencapai objektif kajian ini. Ujian fizikal, ujian kimia, analisis belauan sinar-x, ujian kebolehtelapan, ciri pemadatan, faktor ketermampatan, ujian keruntuhan dan ujian kekuatan ricih diambilkira dalam program ini. Keputusan menunjukkan bahawa tanih bukit pasir Baiji mengutamakan ciri kejuruteraan berdasarkan keadaannya. Oleh itu, tanah ini dianggap sesuai untuk kegunaan pembinaan geoteknikal.

KEYWORDS: Baiji dune sand; Investigation; Compressibility; Collapsibility; Shear Strength; Compaction.

\section{DISTRIBUTION OF SAND DUNES IN IRAQ}

A considerable part of Iraq is covered with sand dunes mainly in the central trough. In general, there are three main regions for sand dunes in Iraq: sand dunes region in the west side of the Euphrates river, sand dunes region in the east side of the Tigris river and sand dunes region between the Tigris and the Euphrates rivers (Fig. 1) [1]. The region between Tigris and Euphrates rivers comprises sand dunes distributed in Hilla, Diwanniya, Nasriyia, Kut and Samawa cities in one hand, and sand dunes area around Baiji city (covering about 230,000,000 square meters), on the other hand [2]. 


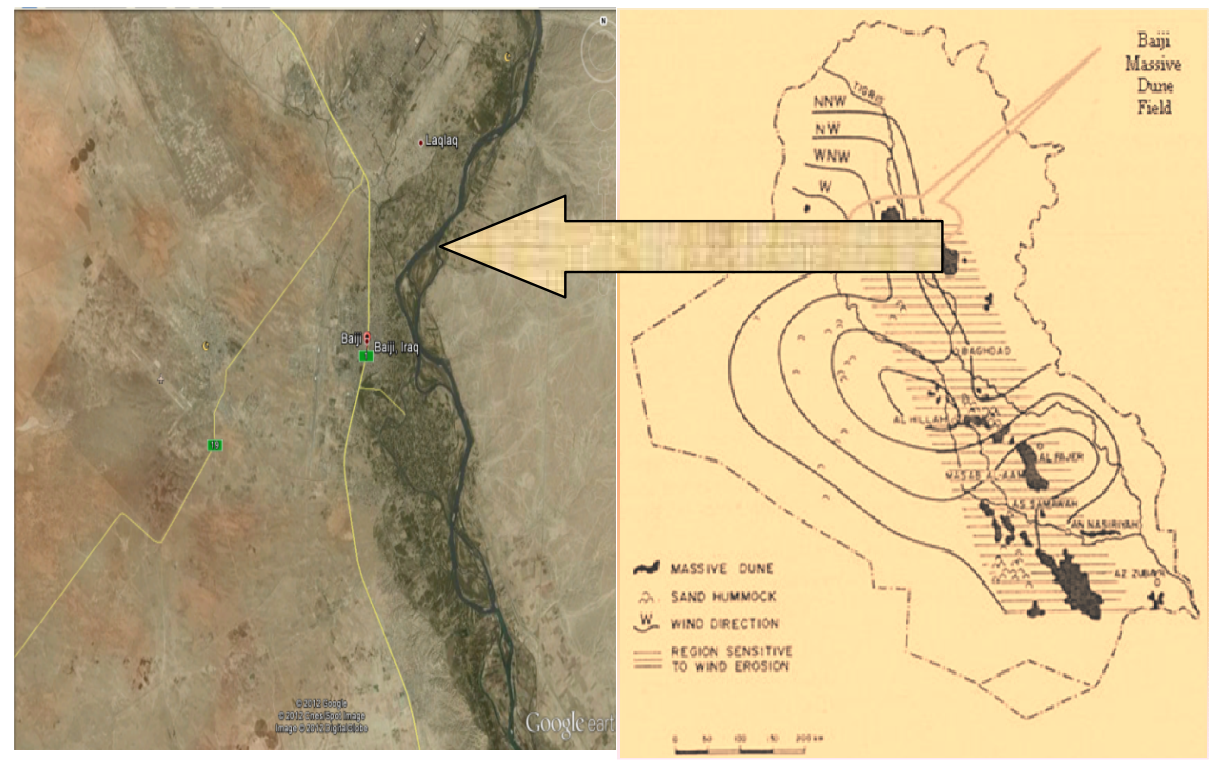

Fig. 1: The desertified area and location of sand dunes in Iraq [5].

\section{SHAPES OF SAND DUNES IN IRAQ}

Sand dunes in Iraq exhibit many shapes depending on the topography and geology of the area and more important on the prevailing wind direction and the presence of vegetation [3]. The dune landform may be an individual barchans dune with a distinctive crescent shape, or fixed dunes that contain irregular shaped, dome shaped and elongated types of dunes. Barchan type dunes are found in Nassiriya, Najaf and Baiji areas. The average area of some barchans found in Baiji is about $500 \mathrm{~m}^{2}$ [4]. Fixed dune of the dome shaped having rounded crests and elongated types are presented in Samawa and Baiji field. They are formed due to the presence of vegetation that covers the dune surfaces and act as obstacles against wind movement as well as traps for sand particles [3].

\section{MATERIALS AND METHODS}

\subsection{Sampling}

To achieve the purpose of this paper, dune sand samples were obtained from the area in Baiji city. The reason to study the soil of this area is the importance of Baiji city since Baiji has very important oil installation like Baiji refinery and the city is a fast growing city. As such, new infra-structures or roads and highways on dune sands connecting different new oil facilities and civil installations may be built. Thus, it is necessary to study the geotechnical properties of Baiji dune soil. However, the dunes in this area consist of three main parts including the barchans belt which lies few kilometers to the northwest from Baiji city, fixed dunes belt around the south of Baiji and scattered patches of dunes west of the main two belts [4]. Samples were taken from the surface of the dune to a shallow depth, then placed in plastic bags, labeled and transported to the laboratory for testing.

\subsection{Testing Program}

A vast laboratory testing program was carried out in accordance with ASTM Standards [6]. Classification tests were performed first. Physical tests include grain size 
distribution, specific gravity, Atterberg limits and minimum and maximum dry density determination. To determine the chemical compounds and the mineral contents of the samples, chemical and X-ray diffraction analyses were performed. To determine the moisture density relationship, standard compaction test was carried out. Permeability test was performed to determine the coefficient of permeability.

A series of shear strength and compressibility tests were conducted on dune sand samples. The tests performed include direct shear, triaxial, standard consolidation and collapse tests.

\section{RESULTS AND DISCUSSION}

\subsection{Simulation Testing on Grain Size Distribution}

The particle size distribution of aeolian sands is often considered as one of the most typical features. During the formation of windblown soils, grains are generally moved by suspension, saltation and surface creep as shown in Fig. 2.

Suspension is the transporting by wind of small particles less than $0.1 \mathrm{~mm}$ in diameter. Saltation is the bouncing, jumping motion of sand grains driven by action of direct wind to form the initial stage of movement. Soil that is moved by saltation consists mainly of fine grains 0.1 to $0.5 \mathrm{~mm}$ in diameter. In surface creep a single grains rolling on the ground, mainly as an effect of saltation impact from smaller grains [7].

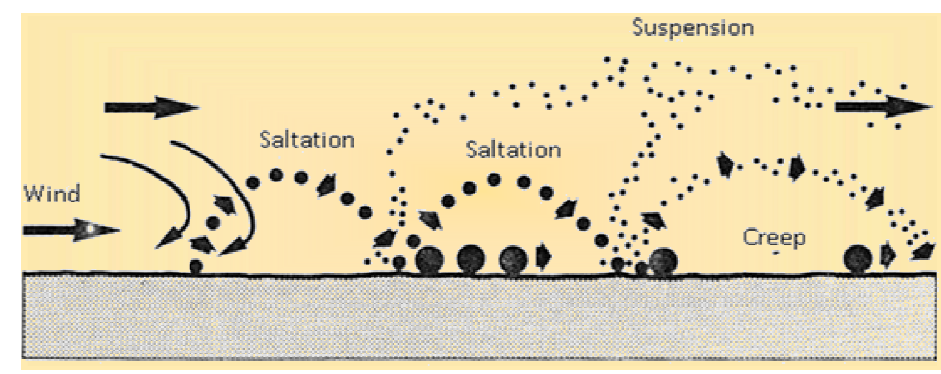

Fig. 2: Methods of grains movement [8].

The particle size distribution test conducted using dry and wet sieve analysis as shown in Fig. 3. One can notice that the particle size distribution curves obtained from both wet and dry sieving of Baiji dune soil are comparatively steep. This steepness indicates the selective sorting of the wind, at which the major part of the mechanical composition of the tested dune sand is ranged from 0.1 to 0.3 millimeters. Sand of this range makes up more than $70 \%$ of the tested soil. Thus, it should expect that when the sweep of wind across Baiji sand dune field, about three-fourth of this sand can moved in saltation. As such, to provide a permanent protection of Baiji sand dune against wind erosion, suitable way depending on major part of the mechanical composition of this soil should be used.

On the other hand, comparative wet and dry sieving of tested dune sand showed only small difference indicating little cementation is available from breakdown by the wet sieving. However, the values of Coefficient of Uniformity $(\mathrm{Cu})$ and Coefficient of Curvature $(\mathrm{Cc})$ were calculated and found to be (1.95) and (1.49) respectively. Also, Fig. 3 compares the grain size distribution of Baiji dune sand and dune sand curve given by Das [9]. One can notice that the particle size distribution curve of Baiji sand is very close to that given by Das [9] where the sands are surprisingly uniform. This uniformity can be 
attributed to the sorting action of the wind $[9,10]$. Finally, it can be concluded that Baiji dune sand is fine and poorly graded sand with nearly no fines.

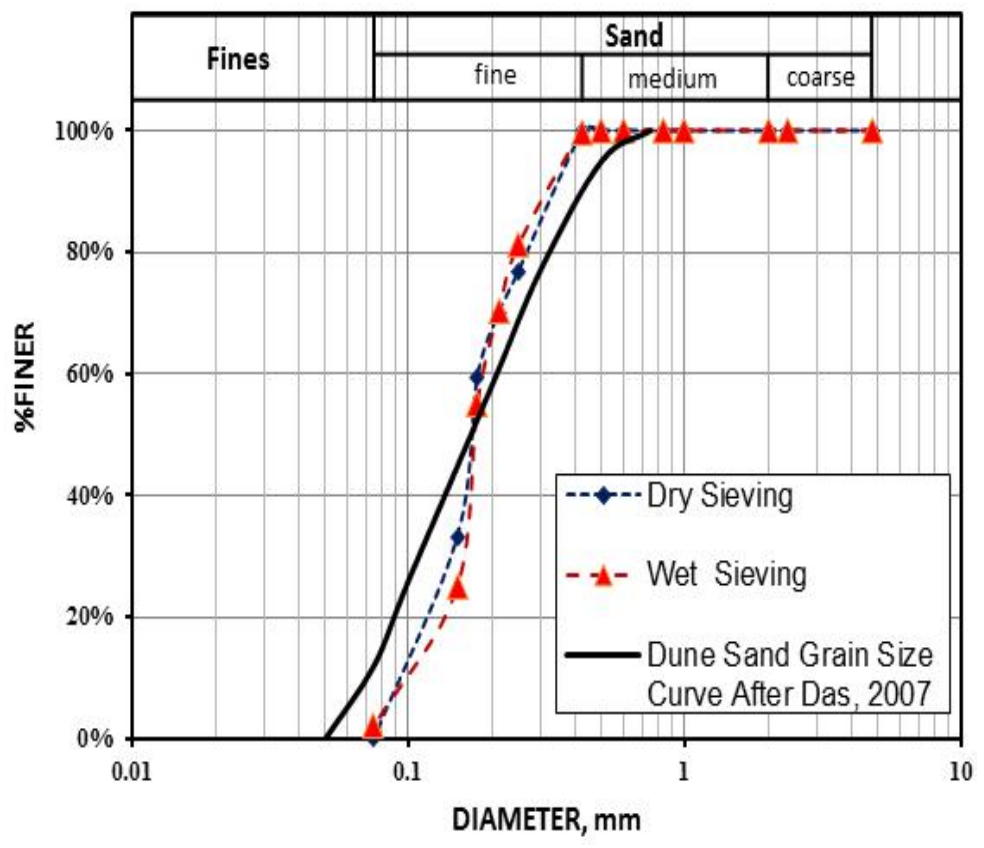

Fig. 3: The particle size distribution curves [9].

\subsection{Soil Classification}

Atterberg limits tests were conducted on natural soil and fractions passing sieve No. 40. The results of the tests are evident that Baiji dune sands are non-plastic in character. The specific gravity of tested soil was determined and found to be 2.70 . On the basis of the results of classification test and according to unified soil classification system, Baiji dune sand can be classified as SP i.e, poorly graded sand.

\subsection{Compaction and Relative Density Tests}

The results of compaction tests are shown in Fig. 4. Irregular curve with one and a half peak are seen from the compaction curve of Baiji dune sand. An initial reduction in density obtained at low moisture content followed by a gradual increase to the peak value. A sharp fall in density generally occurs on the wet side of the optimum. The low density that is obtained when cohesionless soils compacted at low moisture contents is due to capillary forces resisting rearrangements of the sand grains [11]. Also, small films of water around the grains can keep the particles apart and can decrease the density up to particular moisture content [12]. The result of relative density test is plotted in Fig. 4 to be compared the results of standard compaction test. It can be observed that the laboratory vibratory compaction at zero water content achieves high density than standard proctor compaction test; however, the difference is small. 


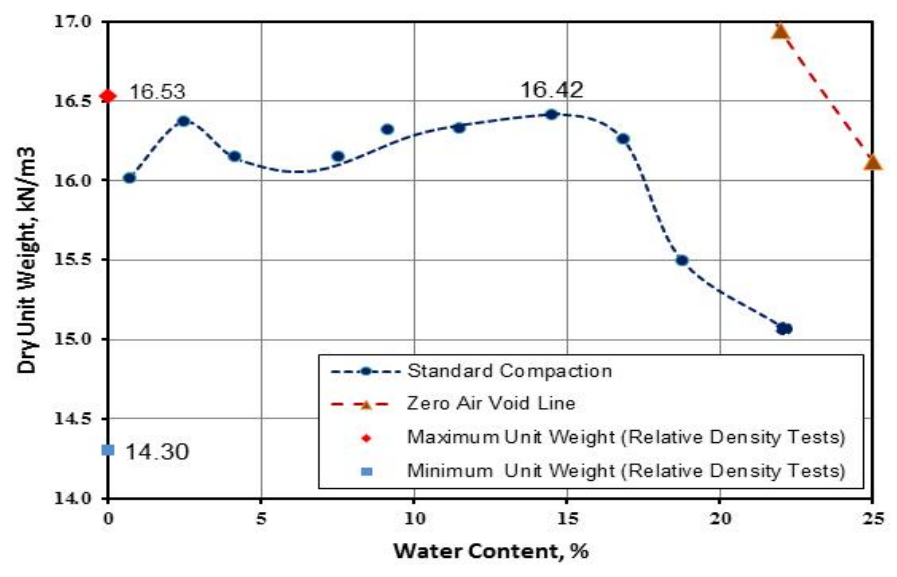

Fig. 4: Compaction and relative density tests results.

Moreover, the ratio of maximum to minimum density of tested sand is 1.156, i.e. small difference can be noticed between the minimum and maximum densities. This may be attributed to the great uniformity of the Baiji sands which leads to conclude that the translation from loose to relatively dense state can be quite abrupt. This means that higher field density can be obtained by applying low compaction effort. Due to the small difference between the maximum and minimum densities of the tested dune sand, the percentage of maximum density, which is more common method of describing the field density, can be misleading measure of the field density of the baiji dune sands. For example, a density of 86 percent of the maximum density is corresponding to a relative density of zero or in other words, to loosest possible packing.

\subsection{The Coeficient of Permeablity}

The constant head permeameter was used to determine the coefficients of permeability of sand specimen prepared with dry unit weight of $16.42 \mathrm{kN} / \mathrm{m}^{3}$ and water content of $14.5 \%$. It is found that the value of coefficient of permeability is $3.4 \times 10^{-4}$ $\mathrm{cm} / \mathrm{sec}$. The relative permeability of the compacted Baiji sands can be classified as "low" [13].

\subsection{Chemical and Mineralogical Composition}

Complete chemical and X-ray diffraction analyses on selected samples were conducted. The results show that silica $\left(\mathrm{SiO}_{2}\right)$ is the main component in Baiji dune sands $(62.79 \%)$, while the percentage of the other components such $\mathrm{R}_{2} \mathrm{O}_{3}, \mathrm{CaO}, \mathrm{MgO}$ are $13.43 \%, 11.06 \%$ and $3.49 \%$, respectively. On the other hand, the amount of sulphates $\left(\mathrm{SO}_{3}\right)$ and chlorides $\left(\mathrm{Cl}^{-}\right)$is very small and nearly zero $\left\{\left(\mathrm{SO}_{3}\right)=0.027 \%,\left(\mathrm{Cl}^{-}\right)=0.026 \%\right\}$. On the other hand, gypsum content in Baiji sand is only $0.27 \%$. The organic matter is almost lacking $(0.1 \%)$ and the $\mathrm{pH}$ value is 8.10 . Mineralogical analysis shows that Baiji dune sand is mainly composed of quartz and calcite $(83 \%)$ and lesser amount of feldspar $(15 \%)$ and mixed layer (2.0\%), while clay minerals are rarely found in this soil (Fig. 5).

\subsection{Collapse Test}

In order to determine the collapse of the natural dune sand specimens and to study the effect of soaking pressure on the collapse potential, a series of single collapse tests with different soaking pressures $(50 \mathrm{kPa}, 100 \mathrm{kPa}$ and $200 \mathrm{kPa})$ were performed. The specimens were prepared with relative density of $50 \%$. The results of tests are shown in Fig. 6 in the form of axial strain-logarithm of vertical pressure curves. As shown, a sudden 
increase in strain occurred as the specimen was flooded with water under a constant stress. Figure 6 is used to determine the change in strain due to saturation, i.e. the collapse potential (cp) and the final strain at vertical pressure of $800 \mathrm{kPa}$ for each soaking pressure.

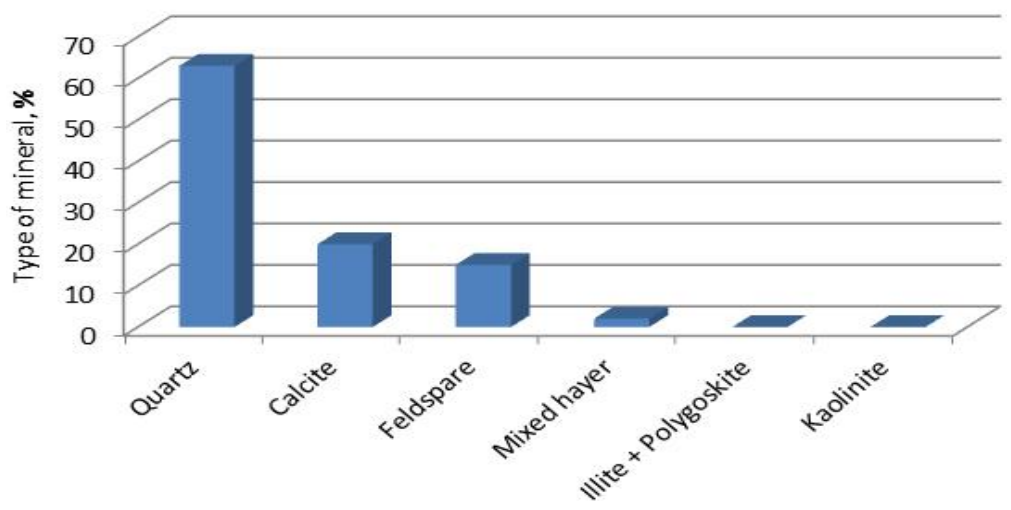

Fig. 5: Mineralogical analysis tests results.

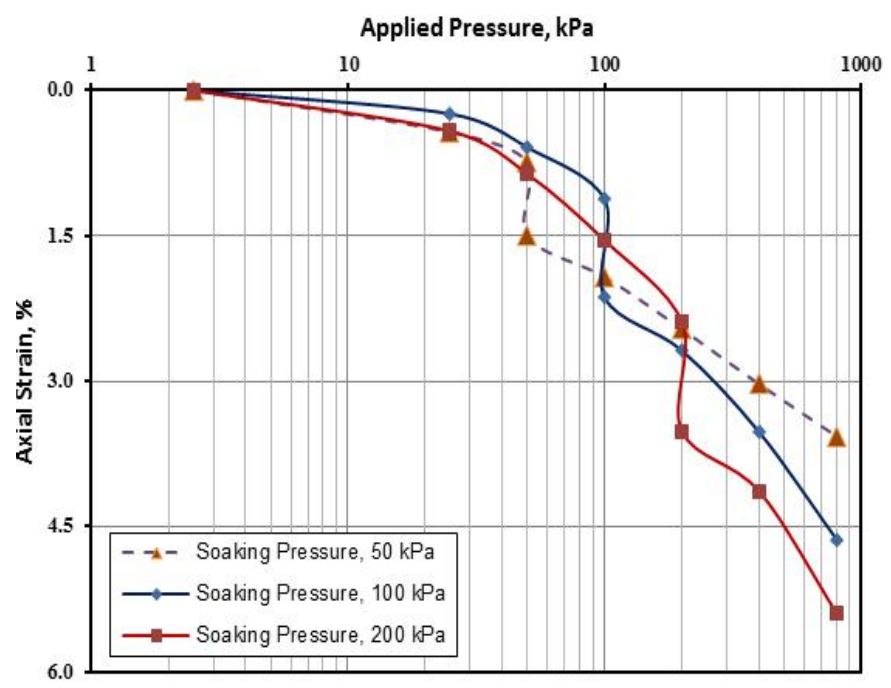

Fig. 6: Single collapse tests results.

The relationship between collapse potential $(\mathrm{CP})$ values, the axial strain at vertical pressure of $800 \mathrm{kPa}$ and soaking pressure are shown in Fig. 7. Examination of Fig. 7 shows that the natural dune sand specimens from Baiji (with $\mathrm{Dr}=50 \%$ ) undergo only small collapse (approximately $1 \%$ at soaking pressure of $200 \mathrm{kPa}$ ). According to ASTM the degree of collapse can be classified as "Slight". The same was found for Kuwait dune sands [14]. Reexamining of Fig. 7 reveals that the collapse potential (CP) increases with the increase of stress level (soaking pressure). The effect of soaking pressure on the axial strain at vertical pressure of $800 \mathrm{kPa}$ is also shown in Fig. 7. As shown, Baiji dune sands exhibit low values of axial strain under different soaking pressure. However, a relative increase in the axial strain with the increase of the soaking pressure of is clearly shown in Fig. 7. 


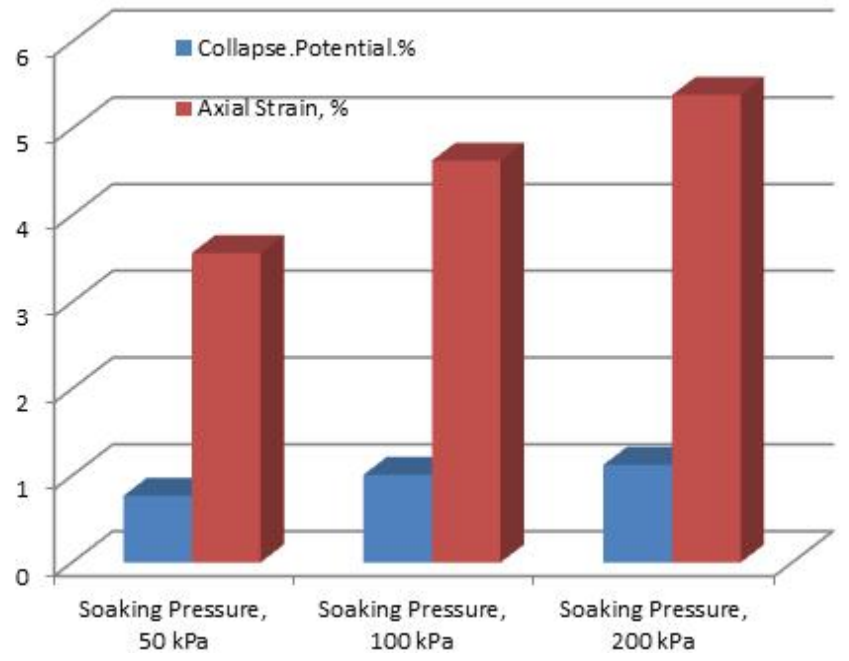

Fig. 7: Collapse Potential (CP) values, the axial strain and soaking pressure.

\subsection{Compression Tests}

Compression tests were carried out on compacted dune sand specimens to determine their compressibility characteristics. The results are presented as void ratio (e), versus logarithm of vertical pressure $(\mathrm{P})$. To investigate the effect of soaking on compressibility characteristics, two groups of specimens were compacted at optimum moisture content to the maximum dry densities obtained from standard Proctor test. The soil in the first group was tested at their initial placement condition (as compacted), and the other one was tested after soaking in water. Table 1 and Fig. 8 and Fig. 9 show the tests results for the two groups. One could notice that the as compacted specimen is less compressible than the soaked one. Compacted Baiji specimens do not have any swell potential, but they have low compression index $\left(\mathrm{C}_{\mathrm{c}}\right)$ and rebound index $\left(\mathrm{C}_{\mathrm{r}}\right)$.

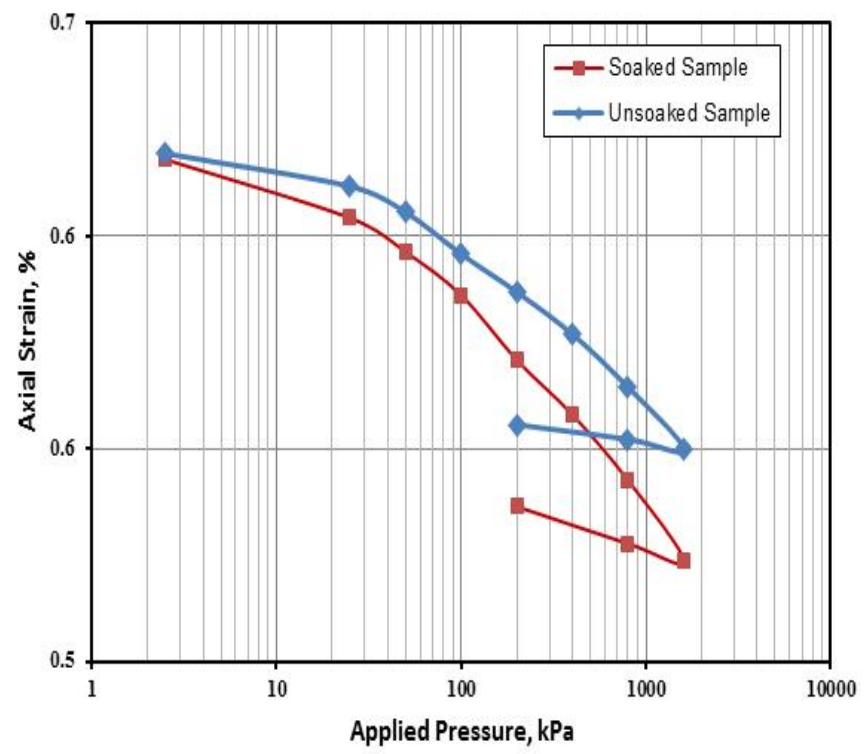

Fig. 8: Compression tests results. 


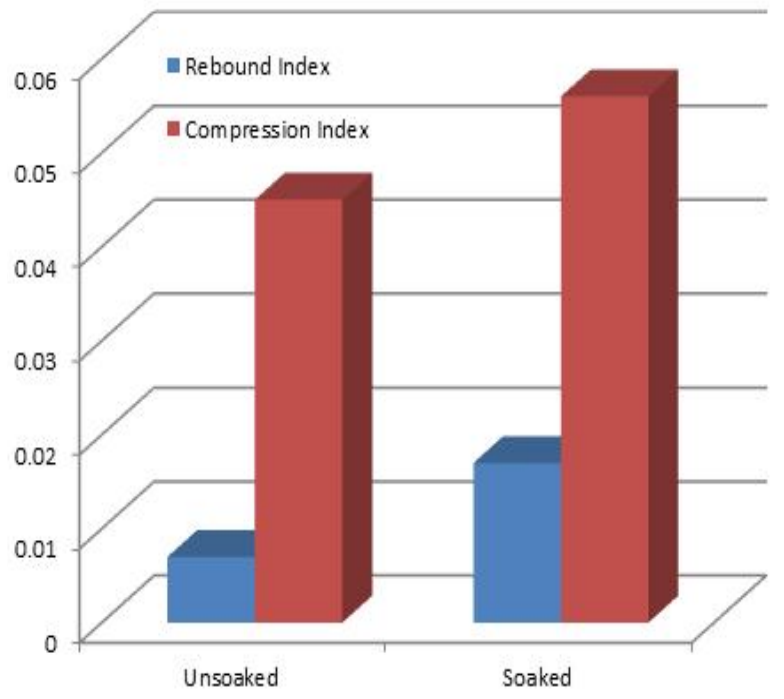

Fig. 9: Compression index $\left(\mathrm{C}_{\mathrm{c}}\right)$ and rebound index $\left(\mathrm{C}_{\mathrm{r}}\right)$.

Table 1: Results of compression test for soaked and as compacted specimens.

\begin{tabular}{ccccc|cccccc}
\hline \multicolumn{3}{c|}{ Compacted Specimens } & \multicolumn{5}{c}{ Soaked Specimens } \\
\hline $\begin{array}{c}\gamma_{\mathrm{d}}, \\
\mathrm{kN} / \mathrm{m}^{3}\end{array}$ & $\omega \%$ & $\mathrm{e}_{\mathrm{o}}$ & $\mathrm{C}_{\mathrm{c}}$ & $\mathrm{C}_{\mathrm{r}}$ & $\begin{array}{c}\gamma_{\mathrm{d}}, \\
\mathrm{kN} / \mathrm{m}^{3}\end{array}$ & $\omega \%$ & $\mathrm{e}_{\mathrm{o}}$ & $\mathrm{C}_{\mathrm{c}}$ & $\mathrm{C}_{\mathrm{r}}$ \\
16.44 & 14.5 & 0.642 & 0.045 & 0.007 & 16.44 & 14.50 & 0.642 & 0.056 & 0.017 \\
\hline
\end{tabular}

\subsection{Shear Tests: Direct Shear Tests}

A series of quick direct shear test was conducted on natural specimens to determine the shear strength parameters. Two identical groups of natural soil were tested. Each group consists of four similar specimens each were prepared with relative density of $50 \%$. The soil in the first group was tested at dry condition, while the second group was soaked in water to about two hours then sheared. A summary of the results is given in Table 2. The stress-strain curves for dry and soaked specimens are shown in Fig. 10. It can be noticed that the shear stress of tested sand increases from zero to a peak value and then gradually decreases and reaches an ultimate or residual value.

The vertical displacement horizontal displacement relationships are also shown in Fig. 11. It can be observed that dry and soaked specimens of baiji specimens tested at dry and soaked conditions exhibited similar volume changes during shear, where the volume of the specimen decrease up to $3 \mathrm{~mm}$ of horizontal displacement and with further displacement the volume increases (dilated) up to approximately $7 \mathrm{~mm}$ of horizontal displacement then decreases, but the final result is volume increasing. This behaviour may be due to the great uniformity of the sand tested, being mainly fine sand. The strength envelopes for sands tested is shown in Fig. 12.

The corresponding parameters are also presented in Table 2. The results have pointed out that the cohesion parameter is equal to zero in Baiji sands tested at natural dry state and after soaking. Moreover, dry and soaked specimens from Baiji dune showed almost identical friction angles, they are $41^{\circ}$ and $39^{\circ}$ respectively. In other words, the coefficient 
of friction $(\tan \varphi)$ for Baiji sand decreases due to soaking to about $6 \%$ which indicated that the shear strength of Baiji sand has low sensitivity to saturation.

Table 2: Results of direct shear tests for the natural specimens.

\begin{tabular}{|c|c|c|c|c|c|c|c|c|}
\hline \multicolumn{4}{|c|}{ Dry } & \multicolumn{4}{|c|}{ Soaked } & \multirow{2}{*}{$\begin{array}{c}\% \text { decrease } \\
\text { in } \\
\tan \Phi\end{array}$} \\
\hline $\begin{array}{c}\sigma_{\mathbf{n}} \\
(\mathbf{k P a})\end{array}$ & $\begin{array}{c}\tau_{\max } \\
(\mathbf{k P a})\end{array}$ & $\begin{array}{c}c \\
(\mathbf{k P a})\end{array}$ & $\begin{array}{c}\Phi \\
\text { (deg.) }\end{array}$ & $\sigma_{\mathrm{n}}(\mathrm{kPa})$ & $\begin{array}{c}\tau_{\max } \\
(\mathbf{k P a})\end{array}$ & $\begin{array}{c}c \\
(\mathbf{k P a})\end{array}$ & $\begin{array}{c}\Phi \\
(\text { deg.) }\end{array}$ & \\
\hline 82.5 & 62.7 & \multirow{4}{*}{0} & \multirow{4}{*}{41} & 82.5 & 58.9 & \multirow{4}{*}{0} & \multirow{4}{*}{39} & \multirow{4}{*}{6.8} \\
\hline 165 & 126.3 & & & 165 & 111.2 & & & \\
\hline 247.5 & 180.4 & & & 247.5 & 161.8 & & & \\
\hline 330 & 244 & & & 330 & 222.5 & & & \\
\hline
\end{tabular}

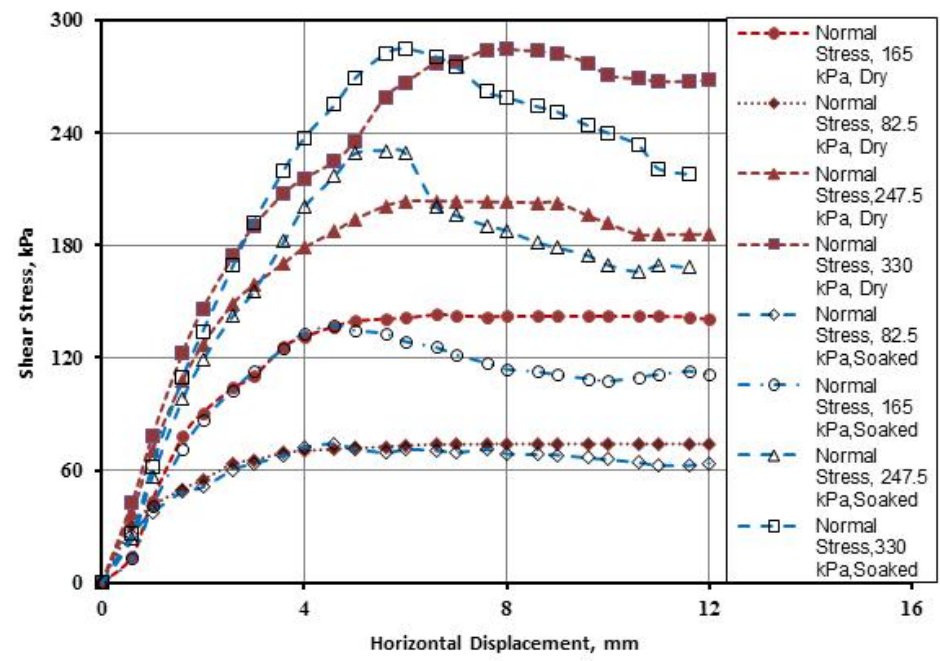

Fig. 10: The stress-strain curves for dry and soaked specimens.

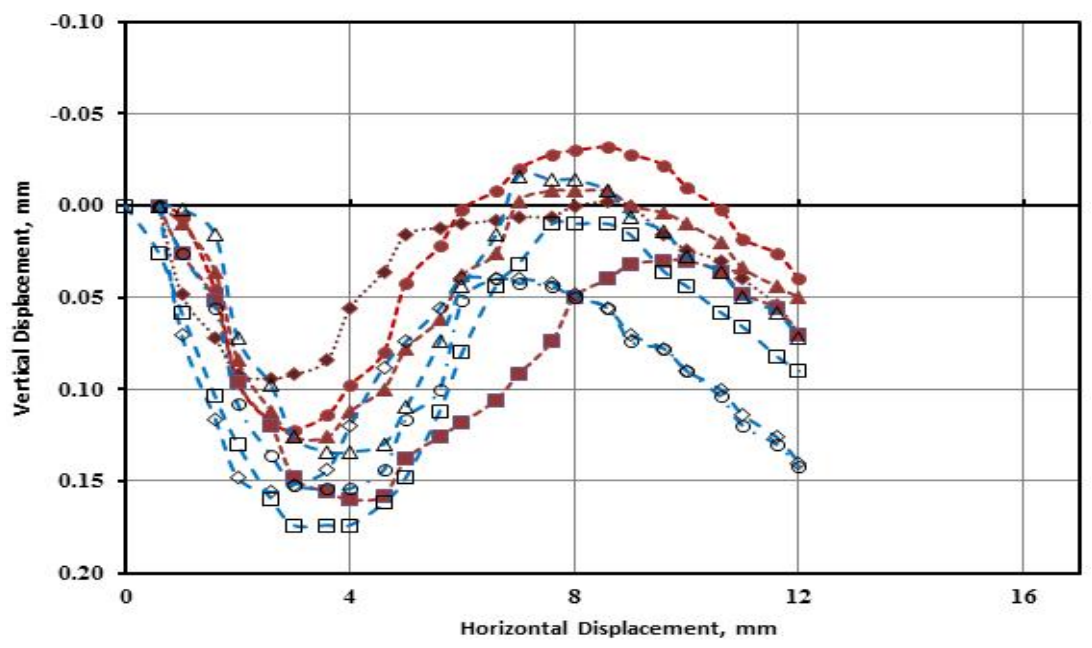

Fig. 11: The vertical displacement-horizontal displacement relationships. 


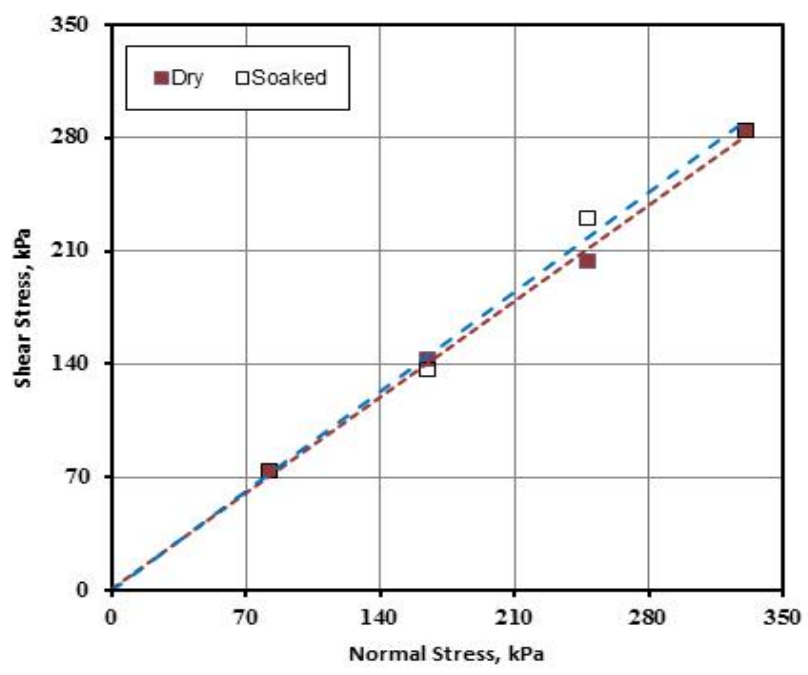

Fig. 12: The strength envelopes.

The corresponding parameters are also presented in Table 2. The results have pointed out that the cohesion parameter is equal to zero in Baiji sands tested at natural dry state and after soaking. Moreover, dry and soaked specimens from Baiji dune showed almost identical friction angles, they are $41^{\circ}$ and $39^{\circ}$ respectively. In other words, the coefficient of friction $(\tan \varphi)$ for Baiji sand decreases due to soaking to about $6 \%$ which indicated that the shear strength of Baiji sand has low sensitivity to saturation.

The angle between the horizontal and the slope of a heap produced by pouring dry sand from a small height, i.e., the angle of repose was determined and compared with the angle of internal friction for loose state. For Baiji sand it is found that the value of the angle of repose is equal to $31^{\circ}$. It is interesting to note that the numerical value of the angle of internal friction obtained from shear tests is greater than that of the angle of repose.

\subsection{Triaxial Compression Tests}

The investigation of the shear behavior of Baiji dune sands was also included unconsolidated untrained triaxial testing of three identical specimens each was prepared at optimum moisture content and maximum dry density corresponding to the standard compaction curve. The test was performed under different all round pressure. The sequence of all round pressure was 100,200 and $400 \mathrm{kPa}$. The results are listed in Table 3. The principal stress difference versus the axial strain, Mohr circles (corresponding to peak strength), and corresponding Mohr envelope are shown in Fig. 13 and Fig. 14.

Table 3: Results of triaxial tests.

\begin{tabular}{|c|c|c|c|c|c|}
\hline$\gamma_{d}, \mathrm{kN} / \mathrm{m}^{3}$ & $\omega, \%$ & $\mathrm{c}, \mathrm{kPa}$ & $\Phi$, deg. & $\sigma_{n}, \mathrm{kPa}$ & $\tau_{\max }, \mathrm{kPa}$ \\
\hline & & & & 100 & 114.2 \\
\hline \multirow[t]{2}{*}{16.4} & 14.5 & 4.25 & 39.5 & 200 & 281.6 \\
\hline & & & & 400 & 547.9 \\
\hline
\end{tabular}

It was found that Baiji dune sand reveals a peaked stress-strain curves with a peak strength increased with the increase in confining pressure. Also, it is obvious that these 
curves show three stages. An initial stage consists of an approximately straight portion in which the stress increased rapidly with strain then tends to curve in the second stage in which stress increased uniformly at much lower rate until it reached a peak value then it decreased gradually with the increase in strain in the last stage.

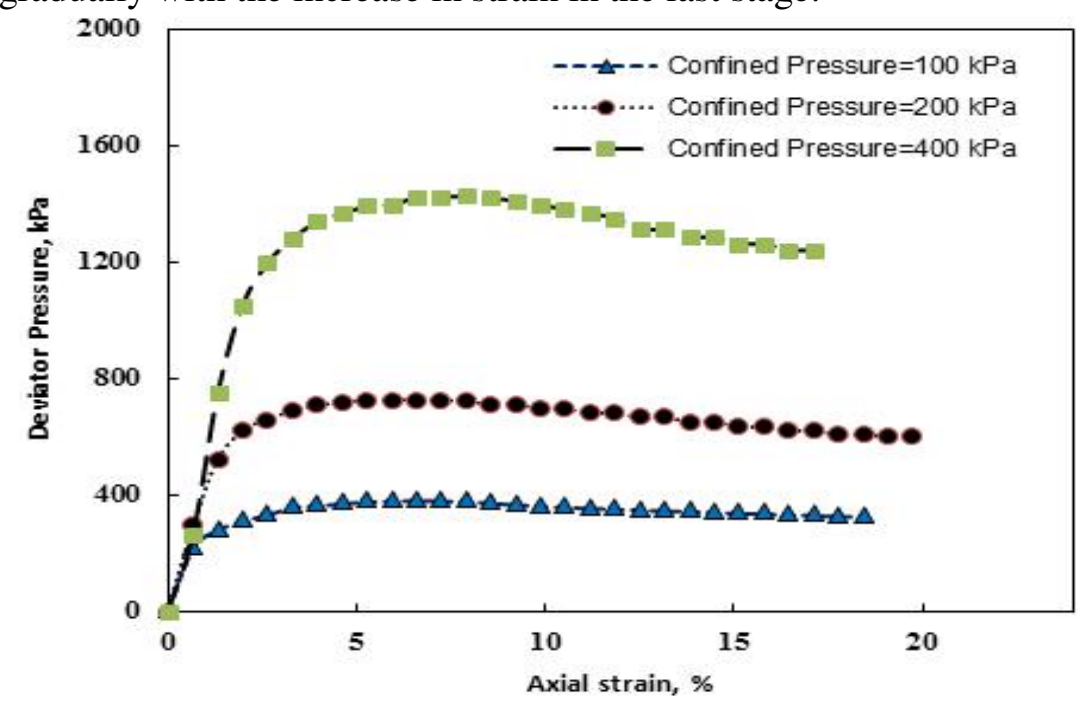

Fig. 13: The principal stress difference versus the axial strain.

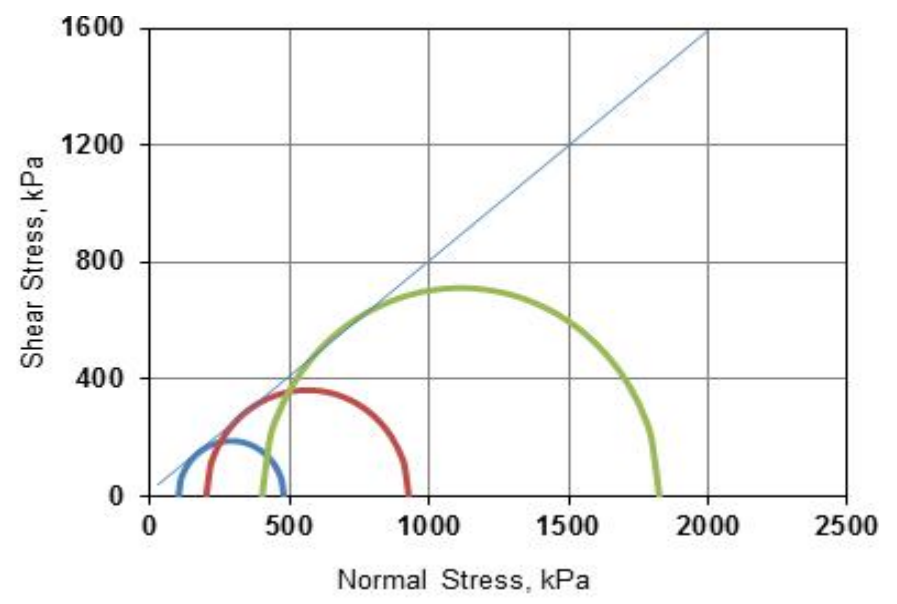

Fig. 14: Mohr circles and the corresponding Mohr envelop.

\section{CONCLUSION}

a) Baiji dune sands have steep and single sized grading curve. To prevent the movement of the dune against wind action, suitable way depending on major part of the mechanical composition of this soil should be used.

b) The silica is the main component in Baiji dune sands. The amount of the sulphates and chlorides is very small and nearly zero, furthermore, the organic matter is almost lacking in this soil

c) Vibration is very effective in compacting dry Baiji dune sands than standard Proctor compaction. Moreover, high field density can be obtained by applying low compaction effort. 
d) Baiji dune sands undergo only small collapse. The degree of collapse of this soil is classified as "Slight". Also, this soil exhibit low values of axial strain under different soaking pressure.

e) Baiji dune sands do not have any swell potential, they have low compression index and rebound index. The degree of compressibility of this soil is classified as "Slight or Low".

f) The shear strength of Baiji dune sands has low sensitivity to saturation. The cohesion parameter is equal to zero. The angle of internal friction of this soil at dense state is $39^{\circ}$ to $41^{\circ}$.

g) Finally, according to results presented in this paper, Baiji dune soil can be considered suitable for use in geotechnical constructions.

\section{REFERENCES}

[1] Al-Rayhanee, A. M.,. Desertification in Iraq and Their Effect on Natural Resources Investment, PhD. Thesis, College of arts . Baghdad University, Iraq.(1986)

[2] Al-Taie, A.J., Properties and Behavior of Dune Sand as a Construction Material. M.Sc. thesis, Civil Engineering Dept., University of Baghdad, Iraq.(1986)

[3] Al-Ani, R.A. Sediment logical and Geomorphologic Study of Sand Dunes in Najaf, Samawa and Nasiriya Area. M.Sc. thesis, College of Science, Baghdad University, Iraq.(1979)

[4] Al-Saadi, S.N. Geomorphology, Sedimentology and Origin of Baiji Dune Field. M.Sc. Thesis, College of Science. Baghdad University, Iraq.(1971)

[5] Gati, F., 1984. Controlling Sand Dune Encroachment in Iraq. Desertification Control Bullentin. 11 (1984): 22-26.

[6] ASTM, 2003, American Society for Testing Materials. ASTM Standards, Volume 04.08.

[7] UNEP , 1998. Manual for Sand Dune Management in the Wider Cribbean, Gillian Cambers of the University of Puerto Rico, through the United Nations Environment Programme (UNEP).

[8] FAO, Sand Dune Stabilization, Conservation Guide, Food and Agriculture Organization of the United Nations Rome. 10 (1992).

[9] Das, B. D., 2005. Fundamentals of Geotechnical Engineering, Third Edition, Thomson.

[10] Albusoda, B. S., and Salem, L., A., Bearing Capacity of Shallow Footings Resting on Dune Sands, Journal of Engineering,. 18.3 (2012): 298-308.

[11] Lambe, T.W., and Whiteman, R.V., Soil Mechanics. John Wiley and Sons, Inc, (1969).

[12] Murthy, V.N.S., Soil Mechanics and Foundation Engineering. SAI Kripa Technical Consultants Bangalore. 1 (1989).

[13] Kulhawy, F. H., and Mayne, P. H., 1990. Manuel on Estimating Soil Properties for Foundation Design. Electric Power Research Institute, EPRI.(1990).

[14] Al-Sanad, H. A., Ismael, N.F. and Nayfeh, A.J. Geotechnical Properties of Dune Sands in Kuwait. Engineering Geology,. 34.1 (1993):45-57.

\section{NOMENCLATURE}

$\mathrm{Cu}$ Coefficient of Uniformity

Cc Coefficient of Curvature

$\mathrm{CP}$ Collapse potential

P Pressure

Cc Compression index

$\mathrm{Cr}$ Rebound index 